\title{
PERIOPERATIVE STEROID ADMINISTRATION INHIBITS ANGIOGENIC HOST TISSUE RESPONSE TO POROUS POLYETHYLENE (MEDPOR ${ }^{\circledR}$ ) IMPLANTS
}

\author{
S. Ehrmantraut ${ }^{1,2}$, M.W. Laschke ${ }^{1, *}$, D. Merkel $^{3}$, C. Scheuer ${ }^{1}$, V. Willnecker ${ }^{3}$, A. Meyer-Lindenberg ${ }^{2}$, M.D. Menger ${ }^{1}$, \\ and A. Naumann ${ }^{3}$ \\ ${ }^{1}$ Institute for Clinical and Experimental Surgery, University of Saarland, D-66421 \\ Homburg/Saar, Germany, \\ ${ }^{2}$ Small Animal Clinic, University of Veterinary Medicine Hannover, \\ Bischofsholer Damm 15, D-30173 Hannover, Germany, \\ ${ }^{3}$ Department of Otorhinolaryngology, Head and Neck Surgery, University of Saarland, \\ D-66421 Homburg/Saar, Germany
}

\begin{abstract}
Porous polyethylene $\left(\right.$ Medpor $\left.^{\circledR}\right)$ is an alloplastic biomaterial, which is commonly used in plastic and reconstructive surgery. In the present study, we analyzed the effect of perioperative steroid administration on the inflammatory and angiogenic host tissue response to implanted Medpor ${ }^{\circledR}$. For this purpose, Medpor ${ }^{\circledR}$ was implanted into the dorsal skinfold chamber of prednisolonetreated and vehicle-treated (control) balb/c mice and analyzed by means of intravital fluorescence microscopy over a 14-day period. Incorporation of the implants was evaluated by histology. An aortic ring assay and Western blot analyses were performed to determine in vitro the effect of prednisolone on angiogenesis. Implantation of Medpor ${ }^{\circledR}$ did not induce a leukocytic inflammatory host tissue response. However, in prednisolone-treated and control animals giant cells could be detected at the interface between the implants and the surrounding granulation tissue as a typical indicator for a chronic foreign body reaction. Interestingly, perioperative prednisolone administration inhibited vascularisation of the implants, as indicated by a significantly decreased functional density of newly developing capillary blood vessels. Accordingly, prednisolone suppressed in vitro endothelial sprouting and tube formation in the aortic ring assay and reduced proliferating cell nuclear antigen (PCNA), Tie2, vascular endothelial growth factor (VEGF) and matrix metalloproteinase (MMP)-9 expression of murine endothelioma cells. In conclusion, prednisolone treatment inhibits the early vascularisation of Medpor ${ }^{\circledR}$ implants due to direct inhibition of distinct angiogenic mechanisms. Therefore, perioperative steroid therapy should be avoided in case of Medpor ${ }^{\circledR}$ implantation to achieve a rapid incorporation of the biomaterial at the implantation site.
\end{abstract}

Key Words: Medpor ${ }^{\circledR}$, polyethylene, angiogenesis, vascularisation, biocompatibility, prednisolone, steroid therapy, incorporation, dorsal skinfold chamber, intravital fluorescence microscopy.

*Address for correspondence:

Matthias W. Laschke

Institute for Clinical and Experimental Surgery

University of Saarland

D-66421 Homburg/Saar, Germany

Telephone Number: +4968411626554

FAX Number: +49 68411626553

E-mail: matthias.laschke@uniklinik-saarland.de
Medpor $^{\circledR}$ is a porous high-density polyethylene, which is widely used as an alloplastic biomaterial in plastic and reconstructive surgery. Widespread indications for the use of Medpor $^{\circledR}$ include auricular reconstruction, augmentation of malar, chin and nasal dorsal areas as well as orbital floor restoration (Duman et al., 1999; Naik et al., 2007). The flexible biomaterial is commercially available in several shapes, sizes and thicknesses (Morton et al., 2000). It can easily be carved, contoured, adapted and fixated to obtain adequate integration into tissue defect sites. Medpor ${ }^{\circledR}$ is non-resorbable and thus provides a good long-term structural stability. Moreover, it has been shown to exhibit a good in vivo biocompatibility (Uysal et al., 2003).

A major prerequisite for the adequate incorporation of Medpor ${ }^{\circledR}$ is a rapid vascularisation of the biomaterial after implantation. Early vascularisation may reduce the overall window during which the implant is susceptible for extrusion, migration and infection (Naik et al., 2007). Medpor $^{\circledR}$ exhibits a porous architecture with an average pore size above $100 \mu \mathrm{m}$. This allows for the ingrowth of new blood vessels from the surrounding host tissue. Nonetheless, early implant vascularisation is not only determined by the porosity of the implanted material, but is also critically dependent on the host tissue's capacity to induce angiogenesis. In this context it should be considered that perioperative steroid administration is commonly used in clinical practice to reduce postoperative oedema formation and to shorten recovery time after facial surgical procedures (Habal, 1985; Kara and Gökalan, 1999; Kargi et al., 2003). This reduction of oedema formation may also improve the incorporation of implanted Medpor ${ }^{\circledR}$ into the surrounding host tissue, diminishing the risk of early implant extrusion, migration and infection. On the other hand, steroids have been shown to exert distinct anti-angiogenic effects in various conditions (Hase et al., 1989; Menger et al., 1990; Banciu et al., 2006). However, it has not been analyzed so far, how steroids affect the early vascularisation of Medpor ${ }^{\circledR}$.

Therefore, the aim of the present study was to investigate the effect of perioperative steroid administration on the inflammatory and angiogenic host tissue response to implanted Medpor ${ }^{\circledR}$. For this purpose, we implanted small pieces of Medpor ${ }^{\otimes}$ into the dorsal skinfold chambers of prednisolone-treated or vehicletreated balb/c mice and analyzed the in vivo biocompatibility and early vascularisation of the implants by means of intravital fluorescence microscopy. 


\section{Materials and Methods}

\section{Animals}

$\mathrm{Balb} / \mathrm{c}$ mice with a body weight of 22-25 $\mathrm{g}$ were used for the study. The animals were housed one per cage and received tap water and standard pellet food (Altromin, Lage, Germany) ad libitum. All experiments were approved by the local governmental animal care committee and were conducted in accordance with the German legislation on protection of animals and the NIH Guidelines for the Care and Use of Laboratory Animals (NIH Publication \#85-23 Rev. 1985).

\section{Dorsal skinfold chamber preparation and Medpor ${ }^{\circledR}$ implantation}

The dorsal skinfold chamber model allows for intravital microscopic observation of the inflammatory and angiogenic host tissue response to implanted biomaterials throughout a time period of 14 days (Laschke et al., 2005; Laschke et al., 2007; Rücker et al., 2008). For chamber preparation, mice were anaesthetized by intraperitoneal (i.p.) injection of ketamine $(75 \mathrm{mg} / \mathrm{kg}$ body weight; Pharmacia GmbH, Erlangen, Germany) and xylazine 2\% (15 mg/kg body weight; Rompun, Bayer; Leverkusen, Germany). Two symmetrical titanium frames were implanted on the extended dorsal skinfold of the animals, so that they sandwiched the double layer of skin. One layer of skin was then completely removed in a circular area of $\sim 15 \mathrm{~mm}$ in diameter, and the remaining layers, consisting of striated skin muscle, subcutaneous tissue and skin, were covered with a removable coverslip within the observation window of one of the titanium frames (Fig. 1A). To exclude alterations of the microcirculation due to anaesthesia and surgical trauma, the mice were allowed to recover for $72 \mathrm{~h}$ before implantation of Medpor ${ }^{\circledR}$.

For our experiments, we used micro-thin sheets of Medpor $^{\circledR}$ (DIM 38 x 50 x 0.25 mm; Porex Surgical Inc.; Newnan, GA, USA), which were carefully cut with a scalpel into small pieces of $3 \times 3 \times 0.25 \mathrm{~mm}$ under a stereomicroscope. Directly before implantation into the dorsal skinfold chamber, the pieces were incubated for 30 $\mathrm{S}$ in antibiotics solution (Nebacetin siccum; Astellas Pharma; München, Germany). Then, the cover glass of the chamber was removed and one piece of Medpor ${ }^{\circledR}$ was placed onto the striated muscle tissue within the centre of each chamber, taking care to avoid contamination, mechanical irritation or damage of the tissue (Fig. 1B).

\section{Intravital fluorescence microscopy}

For in vivo microscopic observation, the mice were fixed on a Plexiglas stage, which allowed for horizontal positioning of the dorsal skinfold chamber under the

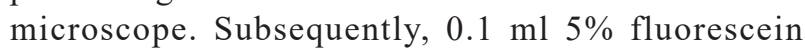
isothiocyanate (FITC)-labeled dextran 150,000 for contrast enhancement by staining of blood plasma and $0.1 \mathrm{~mL} 0.1 \%$ rhodamine 6G (Sigma; Deisenhofen, Germany) for direct in vivo staining of leukocytes were injected intravenously (i.v.) via the retrobulbary space. Intravital fluorescence microscopy was performed by means of a Zeiss Axiotech microscope (Zeiss, Oberkochen, Germany) with a $100 \mathrm{~W}$ mercury lamp attached to an epi-illumination filter block

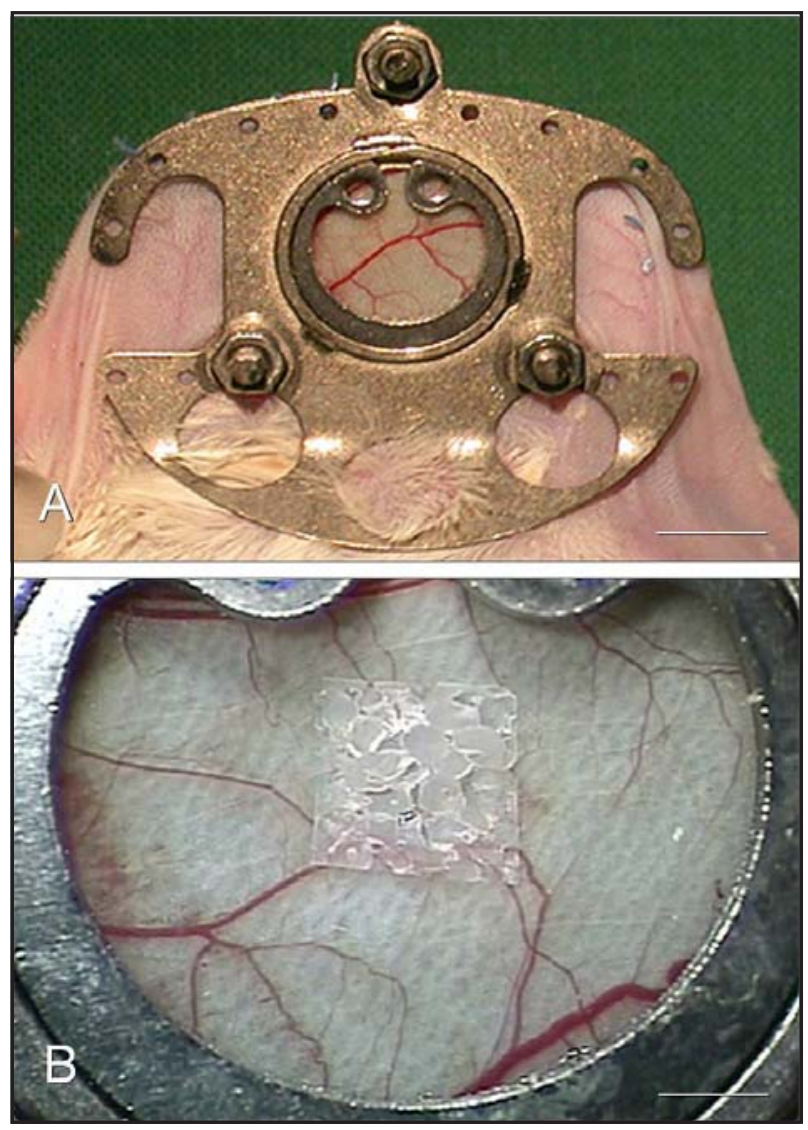

Fig. 1. (A) Titanium chamber (weight $\sim 3$ g) implanted into the dorsal skinfold of a balb/c mouse. Within the observation window the microcirculation of the striated skin muscle and the subcutaneous tissue can be analyzed using trans- and epi-illumination microscopy. (B) Overview of the observation window of a chamber directly after implantation of a small piece of Medpor ${ }^{\circledR}$ (3 x $3 \times 0.25 \mathrm{~mm})$. Scale bars: $\mathbf{A}=6.7 \mathrm{~mm} ; \mathbf{B}=1.7 \mathrm{~mm}$.

for blue, green and ultraviolet light. The microscopic images were recorded by a charge-coupled device video camera (FK6990; Pieper, Schwerte, Germany) and transferred to a DVD system for off-line evaluation. By means of $5 x, 10 x$ and 20x long-distance objectives (Zeiss) magnifications of x115, x230 and x460 were achieved on a 14 inch video screen (KV-14CT1E; Sony, Tokyo, Japan).

\section{Microcirculatory analysis}

Quantitative off-line analysis of the microscopic images was performed using the computer-assisted image analysis system Cap-Image (Dr. Zeintl, Heidelberg, Germany). Leukocyte-endothelial cell interaction and microhaemodynamics were assessed at a magnification of $x 460$ in 4 different microvascular regions of interest (ROIs) in the border zone of the Medpor ${ }^{\circledR}$ implants. In each ROI, 13 postcapillary or collecting venules were selected for analysis.

Leukocytes were classified according to their interaction with the vascular endothelium as rolling or adherent cells (Roller et al., 2008). Rolling leukocytes were defined as cells moving with a velocity less than two-fifths of the centreline velocity, and are expressed as number of cells per minute, passing a reference point within the microvessel. Adherent leukocytes were defined as cells 
that did not move or detach from the endothelial lining of postcapillary venules within a $20 \mathrm{~s}$ observation period, and are expressed as number of cells per square millimetre of venular endothelial surface. Endothelial surface was calculated from the diameter and length of the vessel segment studied, assuming cylindrical vessel geometry.

Diameters, centreline velocity, volumetric blood flow, and wall shear rate were determined in those venules in which leukocyte-endothelial cell interaction was analyzed. Diameters (d) were measured in $\mu \mathrm{m}$ perpendicularly to the vessel path. Centreline red blood cell velocity (v) was analyzed by the computer-assisted image analysis system using the line shift method. Volumetric blood flow was calculated by $\mathrm{Q}=\pi *(\mathrm{~d} / 2)^{2} * \mathrm{v} / 1.6[\mathrm{pL} / \mathrm{s}]$, where 1.6 represents the Baker-Wayland factor (Baker and Wayland, 1974) to correct for the parabolic velocity profile in microvessels with diameters $>20 \mu \mathrm{m}$. Moreover, wall shear rate (y) was calculated based on the Newtonian definition: $\mathrm{y}=8 * \mathrm{v} / \mathrm{d}$.

Angiogenesis was analyzed at a magnification of $\mathrm{x} 460$ in 8 different microvascular regions-of-interest (ROIs) in the border zone and 8 different microvascular ROIs in the centre of the Medpor ${ }^{\circledR}$ implants. ROIs were defined as positive for angiogenesis when signs of blood vessel development, i.e. capillary sprouts or newly formed microvessels ingrowing into the implants, could be identified. In addition, functional capillary density, i.e. the length of newly formed red blood cell (RBC)-perfused capillaries per observation area, was measured by CapImage and is given in $\mathrm{cm} / \mathrm{cm}^{2}$.

\section{Experimental protocol}

Dorsal skinfold chambers were prepared in a total of 15 balb/c mice. After $72 \mathrm{~h}$, Medpor $^{\circledR}$ was implanted into the chambers. Directly as well as $24 \mathrm{~h}$ and $48 \mathrm{~h}$ after implantation, the animals were either treated with prednisolone $(\mathrm{n}=8 ; 3 \mathrm{mg} / \mathrm{kg}$ body weight subcutaneous (s.c.) Solu-Decortin; Merck, Darmstadt, Germany) or aqua inject $(n=7$; control). Prednisolone is normally administered at a dosage of $250 \mathrm{mg}$ per $70 \mathrm{~kg}$ in adult patients as well as $3-6 \mathrm{mg} / \mathrm{kg}$ in children. Accordingly, treatment of mice with a prednisolone dosage of $3 \mathrm{mg} / \mathrm{kg}$ directly reflected the clinical situation in the present study (Gürlek et al., 2009). Intravital fluorescent microscopic analyses of leukocyte-endothelial cell interaction, microhemodynamics and angiogenesis were performed directly after Medpor ${ }^{\circledR}$ implantation as well as at days 3, 6,10 and 14. At the end of the in vivo experiments, the animals were sacrificed with an overdose of the anaesthetics and the dorsal skinfold preparations were excised for histological examinations.

\section{Histology}

For light microscopy, formalin-fixed specimens were embedded in paraffin at day 14 after Medpor ${ }^{\circledR}$ implantation. Four- $\mu \mathrm{m}$-thick sections were cut and stained with haematoxylin and eosin according to standard procedures.

\section{Aortic ring assay}

To study in vitro the effect of prednisolone on the development of new blood vessels, an aortic ring assay was performed, as described previously (Laschke et al., 2008). Aortic rings of male Sprague Dawley rats (250 g body weight) were embedded in $200 \mu \mathrm{L}$ Matrigel (BD MatrigelTM Matrix, BD Biosciences; Heidelberg, Germany) in 48-well tissue culture grade plates and allowed to polymerize for $20 \mathrm{~min}$ at $37^{\circ} \mathrm{C}$ and $5 \% \mathrm{CO}_{2}$. The wells were then overlaid with $800 \mu \mathrm{L}$ of Dulbecco's modified Eagle's medium (DMEM; $10 \%$ foetal calf serum, $1 \mathrm{U} / \mathrm{mL}$ penicillin, $0.1 \mathrm{mg} / \mathrm{mL}$ streptomycin; PAA, Cölbe, Germany) supplemented with $37.5 \mu \mathrm{g} / \mathrm{mL}$ Solu Decortin (=104 $\mu \mathrm{M}$ prednisolone; Merck), which reflects the dose of $3 \mathrm{mg} / \mathrm{kg}$ Solu Decortin given to the mice in the in vivo experiments, or aqua inject, respectively. Subsequently, the rings were maintained at $37^{\circ} \mathrm{C}$ and $5 \% \mathrm{CO}_{2}$ for 6 days with medium change every 2 days. All assays were done in duplicate in a total of four animals. Vascular sprouting from each ring was examined by trans-illumination phasecontrast microscopy. Images were recorded by means of an optronics engineering device (TEC-470; SI GmbH, Gilching, Germany) and transferred to a DVD system for off-line evaluation by means of the Cap-Image software. Quantitative analysis included the determination of the area $\left(\mathrm{mm}^{2}\right)$, the maximal length $(\mu \mathrm{m})$ and the density $\left(\mathrm{cm} / \mathrm{cm}^{2}\right)$ of the outer aortic vessel sprouting.

\section{Western Blot analysis}

To investigate the dose-dependent effect of prednisolone on protein expression of Tie2, vascular endothelial growth factor (VEGF), matrix metalloproteinase 9 (MMP9) and proliferating cell nuclear antigen (PCNA) on endotheliallike cells, we used murine endothelioma cells (eEND2) of passage 2 after cryoconservation, which were cultured for 2 days in DMEM (10\% foetal calf serum, $1 \mathrm{U} / \mathrm{mL}$ penicillin, $0.1 \mathrm{mg} / \mathrm{mL}$ streptomycin; PAA) at $37^{\circ} \mathrm{C}$ and $5 \% \mathrm{CO}_{2}$ until subconfluency. Subsequently, the cells were exposed to $1.25 \mu \mathrm{g} / \mathrm{mL}, 37.5 \mu \mathrm{g} / \mathrm{mL}$ and $112.5 \mu \mathrm{g} / \mathrm{mL}$ Solu Decortin $(=3.5 \mu \mathrm{M}, 104 \mu \mathrm{M}$ and $312 \mu \mathrm{M}$ predinisolone; Merck). Cells exposed to the vehicle (aqua inject) served as controls. All experiments were performed in triplicate. After 24h, cells were harvested with accutase (PAA), frozen in liquid nitrogen and subsequently stored at $-20^{\circ} \mathrm{C}$ for Western blot analysis. For extraction of the whole protein fraction, frozen cells were incubated for $30 \mathrm{~min}$ in lysis buffer (10 mM Tris pH 7.5, $10 \mathrm{mM} \mathrm{NaCl}, 0.1 \mathrm{mM}$ EDTA, $0.5 \%$ Triton-X 100, 0.02\% $\mathrm{NaN}_{3}, 0.2 \mathrm{mM}$ PMSF and Protease-Inhibitor-Cocktail (1:100 v/v; Sigma) $)$ on ice and centrifuged for $30 \mathrm{~min}$ at $16,000 \times \mathrm{g}\left(4^{\circ} \mathrm{C}\right)$. The supernatant was saved as whole protein fraction. Protein concentrations were determined using the Lowry assay with bovine serum albumin (BSA) as standard. Ten $\mu \mathrm{g}$ protein/lane were separated discontinuously on $10 \%$ sodium dodecylsulfate polyacrylamide gels and transferred to a poly-vinyldifluoride membrane (BioRad, München, Germany). After blockade of non-specific binding sites, membranes were incubated for $4 \mathrm{~h}$ with a goat-polyclonal anti-Tie2 antibody (1:300; R\&D Systems, Wiesbaden, Germany), with a rabbit-polyclonal anti-VEGF antibody (A20, 1:100; Santa Cruz; Heidelberg, Germany), with a rabbit-polyclonal anti-MMP9 antibody (1:250; Abcam, Cambridge, UK) and with a mouse-monoclonal antiPCNA antibody (1:2,000; DAKO Cytomation, Hamburg, 
Table 1. Microhaemodynamics in postcapillary and collecting venules after implantation of Medpor ${ }^{\circledR}$.
do
d3
d6
d10
d14

\begin{tabular}{llllll}
\hline Diameter $[\mu \mathrm{m}]:$ & & & & \\
Control & $33.5 \pm 0.6$ & $36.0 \pm 1.1$ & $37.5 \pm 1.7^{\mathrm{a}}$ & $38.8 \pm 1.3^{\mathrm{a}}$ & $34.7 \pm 0.9$ \\
Prednisolone & $35.8 \pm 0.8^{*}$ & $37.5 \pm 1.8$ & $38.3 \pm 1.5$ & $38.0 \pm 1.4$ & $37.8 \pm 1.3$
\end{tabular}

Centreline velocity $[\mu \mathrm{m} / \mathrm{s}]$ :

$\begin{array}{llllll}\text { Control } & 219.9 \pm 54.0 & 340.7 \pm 59.7 & 308.1 \pm 72.6 & 378.9 \pm 62.3 & 445.6 \pm 43.7^{\mathrm{a}} \\ \text { Prednisolone } & 260.0 \pm 38.1 & 371.0 \pm 39.0 & 298.3 \pm 40.5 & 390.9 \pm 49.3 & 402.5 \pm 50.2\end{array}$

Volumetric blood flow $[\mathrm{pL} / \mathrm{s}]$ :

$\begin{array}{llllll}\text { Control } & 123.3 \pm 30.4 & 213.8 \pm 32.9^{\mathrm{a}} & 201.4 \pm 31.9^{\mathrm{a}} & 281.5 \pm 52.0^{\mathrm{a}} & 267.0 \pm 34.4^{\mathrm{a}} \\ \text { Prednisolone } & 161.2 \pm 21.2 & 257.2 \pm 35.9^{\mathrm{a}} & 208.2 \pm 24.6^{\mathrm{a}} & 270.5 \pm 32.6^{\mathrm{a}} & 290.5 \pm 55.1^{\mathrm{a}}\end{array}$

Wall shear rate $\left[\mathrm{s}^{-1}\right]$ :

\begin{tabular}{llllll} 
Control & $52.2 \pm 12.8$ & $76.8 \pm 14.7$ & $69.0 \pm 19.8$ & $78.6 \pm 12.7$ & $102.7 \pm 9.4^{\mathrm{a}}$ \\
Prednisolone & $58.8 \pm 9.2$ & $80.5 \pm 8.9$ & $64.2 \pm 9.9$ & $83.9 \pm 11.0$ & $85.1 \pm 9.6$ \\
\hline
\end{tabular}

Diameter $(\mu \mathrm{m})$, centreline velocity $(\mu \mathrm{m} / \mathrm{s})$, volumetric blood flow $(\mathrm{pL} / \mathrm{s})$ and wall shear rate $\left(\mathrm{s}^{-1}\right)$ of postcapillary and collecting venules within the border zones of Medpor ${ }^{\circledR}$ directly $(\mathrm{d} 0)$ as well as 3, 6, 10 and 14 days after implantation into dorsal skinfold chambers of vehicle-treated (control) and prednisolone-treated balb/c mice. Means $\pm \mathrm{SEM}$. ${ }^{a} P<0.05$ vs. d0 within each individual group. ${ }^{*} P<0.05$ vs. control at corresponding time points.

Table 2. Leukocyte-endothelial cell interaction in postcapillary and collecting venules after implantation of Medpor ${ }^{\circledR}$.
do
d3
d6
d10
d14

\begin{tabular}{|c|c|c|c|c|c|}
\hline \multicolumn{6}{|c|}{ Rolling leukocytes $\left[\mathrm{min}^{-1}\right]$ : } \\
\hline Control & $26.8 \pm 5.1$ & $30.3 \pm 4.4$ & $22.7 \pm 3.3$ & $24.4 \pm 3.8$ & $27.2 \pm 6.6$ \\
\hline Prednisolone & $21.0 \pm 2.1$ & $27.5 \pm 3.0$ & $29.2 \pm 1.9$ & $23.4 \pm 1.8$ & $31.4 \pm 3.4^{\mathrm{a}}$ \\
\hline \multicolumn{6}{|c|}{ Adherent leukocytes $\left[\mathrm{mm}^{-2}\right]$ : } \\
\hline Control & $185.2 \pm 19.7$ & $144.1 \pm 16.3$ & $184.3 \pm 13.1$ & $175.8 \pm 21.7$ & $187.2 \pm 17.0$ \\
\hline Prednisolone & $244.9 \pm 25.2$ & $191.0 \pm 27.4$ & $165.1 \pm 29.5$ & $199.6 \pm 47.1$ & $146.6 \pm 23.9$ \\
\hline
\end{tabular}

Numbers of rolling leukocytes $\left(\mathrm{min}^{-1}\right)$ and adherent leukocytes $\left(\mathrm{mm}^{-2}\right)$ in postcapillary and collecting venules within the border zones of Medpor ${ }^{\circledR}$ directly (d0) as well as 3, 6, 10 and 14 days after implantation into dorsal skinfold chambers of vehicle-treated (control) and prednisolone-treated balb/c mice. Means $\pm \mathrm{SEM}$. ${ }^{\mathrm{a}} \mathrm{P}<0.05$ vs. d0 within each individual group.

Germany) followed by the corresponding horseradish peroxidase (HRP)-conjugated secondary antibodies (1:5,000; GE Healthcare; Freiburg, Germany). Protein expression was visualized using luminol-enhanced chemiluminescence and exposure of membranes to blue light-sensitive autoradiography film (Hyperfilm ECL, GE Healthcare). Signals were densitometrically assessed (Geldoc, Quantity one software, BioRad) and normalized to $\beta$-actin signals (mouse anti- $\beta$-actin antibody, $1: 15,000$; Sigma) to correct unequal loading.

\section{Statistics}

After testing the data for normal distribution and equal variance, differences between two groups were analyzed by the unpaired Student's $t$-test and differences between multiple groups were analyzed by ANOVA followed by the appropriate post hoc comparison. To test for time effects in the individual groups, ANOVA for repeated measures was applied. This was followed by the Student-NewmanKeuls test including the correction of the alpha error according to Bonferroni probabilities to compensate for multiple comparisons (SigmaStat; Jandel Corporation, San Rafael, CA, USA). All values are expressed as means \pm SEM. Statistical significance was accepted for a value of $P<0.05$.

\section{Results}

\section{Intravital fluorescence microscopy}

To study in vivo the leukocytic inflammatory response of the host tissue to implanted Medpor ${ }^{\circledR}$, leukocyte- 

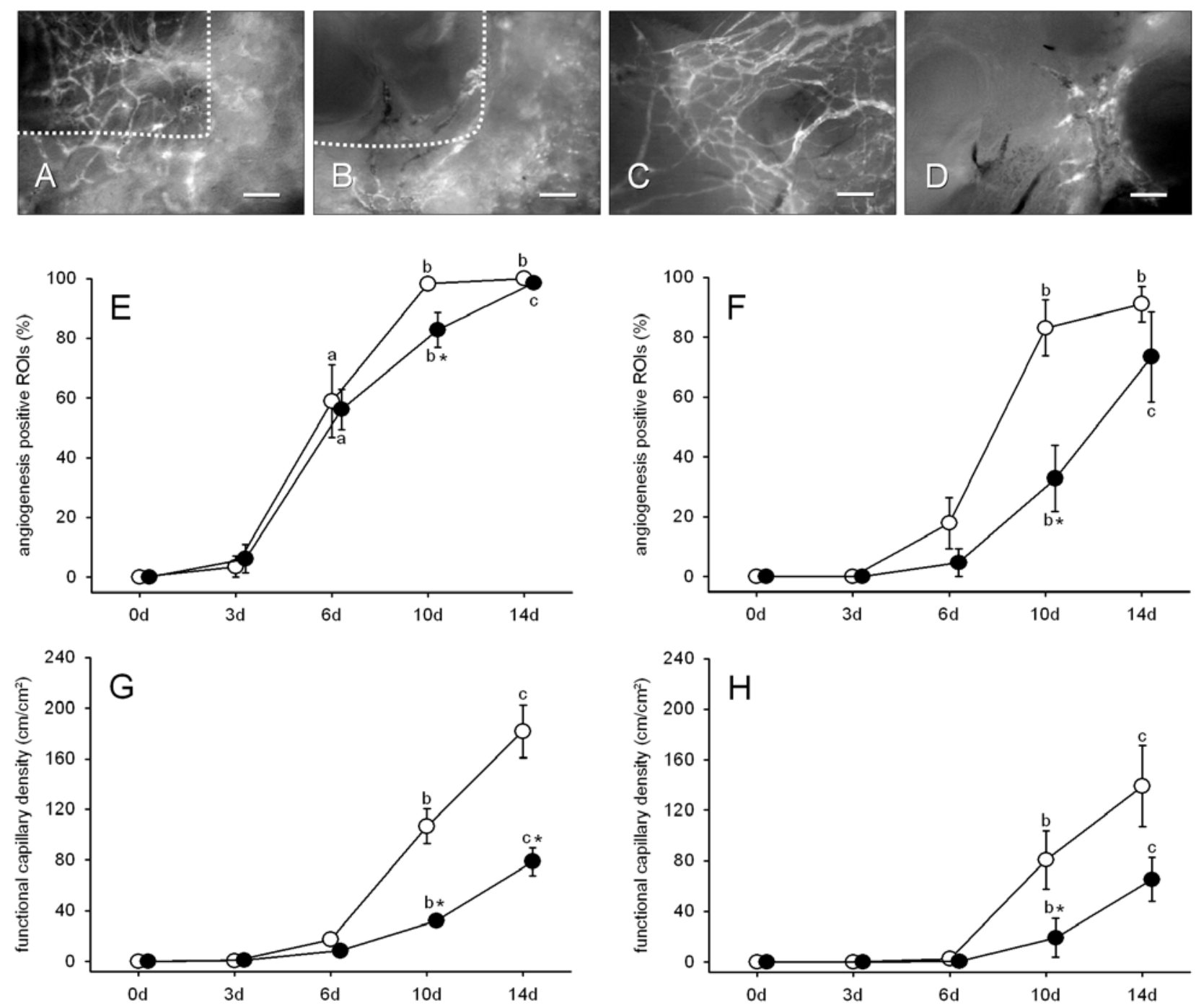

Fig. 2. Intravital fluorescence microscopy of microvascular regions of interest (ROIs) at the border (A, B; marked by dotted white line) and the centre $(\mathbf{C}, \mathbf{D})$ of Medpor ${ }^{\circledR}$ implants at day 14 after implantation into the dorsal skinfold chamber of a vehicle-treated $(\mathbf{A}, \mathbf{C})$ and a prednisolone-treated $(\mathbf{B}, \mathbf{D}) \mathrm{balb} / \mathrm{c}$ mouse. Note that the border and the centre of the Medpor ${ }^{\circledR}$ implant of the vehicle-treated animal is covered by a dense network of newly formed microvessels, while only a few microvessels can be detected in corresponding ROIs of the Medpor ${ }^{\circledR}$ implant of the prednisolone-treated mouse (B, D). Blue light epi-illumination with contrast enhancement by 5\% FITClabelled dextran 150,000 i.v.. Scale bars: $90 \mu \mathrm{m}$. E-H: Analysis of angiogenesis positive ROIs (\%) (E, F) and functional capillary density $\left(\mathrm{cm} / \mathrm{cm}^{2}\right)(\mathbf{G}, \mathbf{H})$ within the border $(\mathbf{E}, \mathbf{G})$ and the centre $(\mathbf{F}, \mathbf{H})$ of Medpor ${ }^{\circledR}$ after implantation into the dorsal skinfold chambers of vehicle-treated (control; white circles) and prednisolone-treated (black circles) balb/c mice, as assessed by intravital fluorescence microscopy and computer-assisted image analysis. Means \pm SEM. ${ }^{a} P<0.05$ vs. $0 \mathrm{~d}$ and $3 \mathrm{~d}$ within each individual group; ${ }^{b} P<0.05$ vs. $0 \mathrm{~d}, 3 \mathrm{~d}$ and $6 \mathrm{~d}$ within each individual group; ${ }^{c} P<0.05$ vs. $0 \mathrm{~d}, 3 \mathrm{~d}, 6 \mathrm{~d}$ and $10 \mathrm{~d}$ within each individual group; ${ }^{*} P<0.05$ vs. control at corresponding time points.

endothelial cell interaction was analyzed in postcapillary and collecting venules of the chamber tissue located in the border zones of the implants. The diameters of these microvessels ranged between 34-39 $\mu \mathrm{m}$ without marked differences between prednisolone-treated and control mice (Table 1). Throughout the observation period of 14 days, centreline velocity of vessels in both groups progressively increased from 220-260 $\mu \mathrm{m} / \mathrm{s}$ directly after Medpor ${ }^{\circledR}$ implantation to $403-446 \mu \mathrm{m} / \mathrm{s}$ at day 14 , which is most probably due to the induction of angiogenesis at the site of implantation (Table 1). Accordingly, calculated values of volumetric blood flow and wall shear rate also showed an increase over time, however, without significant differences between the two groups (Table 1). These results clearly indicate that prednisolone treatment did not affect microhaemodynamics and microcirculation, and that the analysis of leukocyte-endothelial cell interaction, which may be influenced by altered microhaemodynamic parameters (Kim and Sarelius, 2004), could be analyzed under standardized microcirculatory conditions.

In both experimental groups, numbers of rolling and adherent leukocytes ranged between 21-31 $\mathrm{min}^{-1}$ and 144$245 \mathrm{~mm}^{-2}$ throughout the observation period (Table 2). Compared to other biomaterial studies performed in the same model (Rücker et al., 2006), these results indicate that the Medpor ${ }^{\circledR}$ implants exhibit a good in vivo 


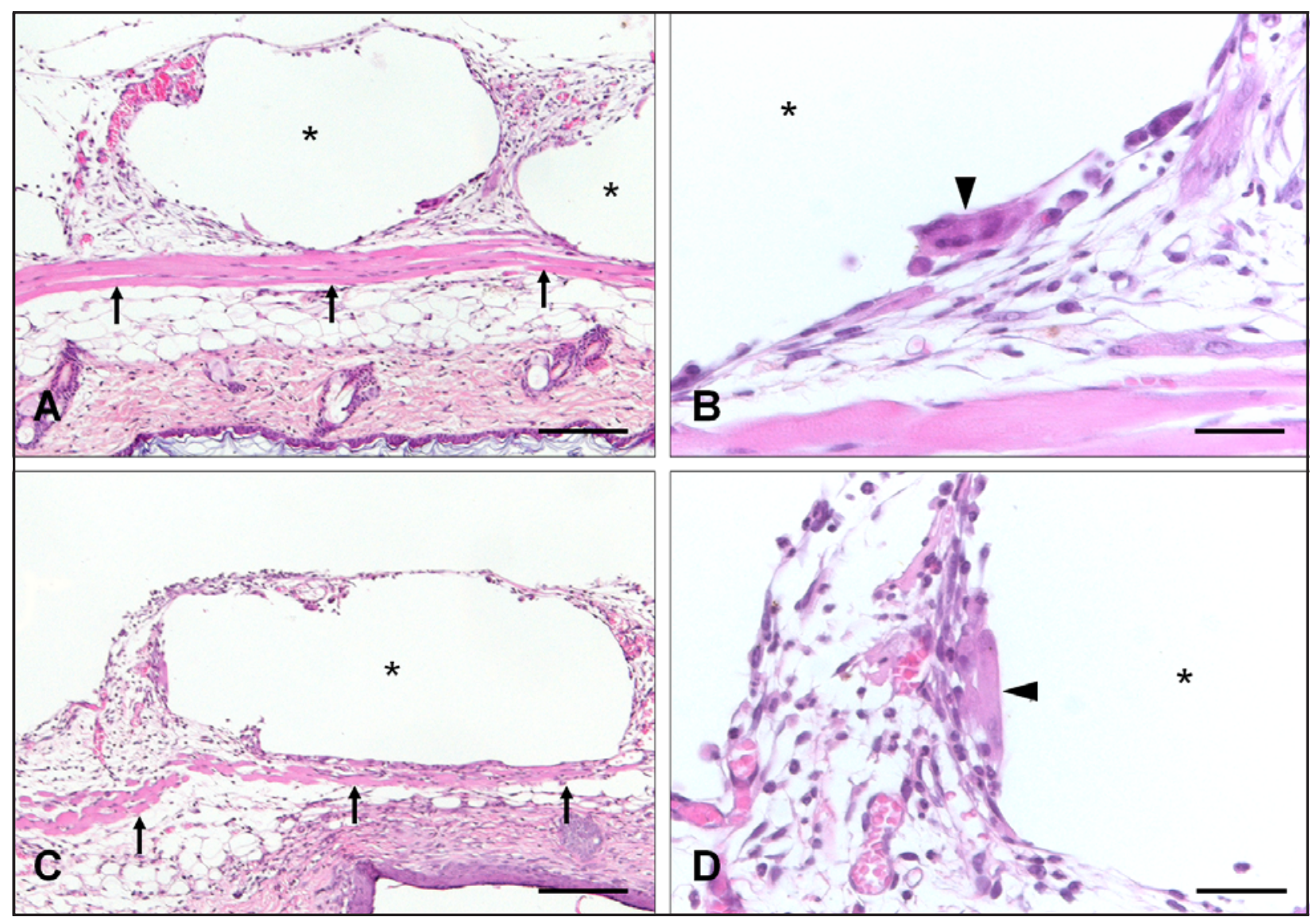

Fig. 3. Haematoxylin-eosin stained cross sections of Medpor ${ }^{\circledR}$ implants at day 14 after implantation onto the striated muscle tissue (A, C, arrows) of the dorsal skinfold chamber of a vehicle-treated (A, B) and a prednisolone-treated (C, D) balb/c mouse. Note that the implants (asterisks) are surrounded by a vascularised granulation tissue (A, C). Individual foreign body giant cells (arrow heads) can be detected in higher magnification at the interface between the Medpor $^{\circledR}$ implants and the surrounding granulation tissue $(\mathbf{B}, \mathbf{D})$. Scale bars: A, C $=125 \mu \mathrm{m} ; \mathbf{B}, \mathbf{D}=35 \mu \mathrm{m}$.

biocompatibility without inducing a strong leukocytic inflammatory response after implantation. In addition, prednisolone treatment did not affect the interaction of leukocytes with the microvascular endothelium at the implantation site.

In control animals, Medpor ${ }^{\circledR}$ induced an angiogenic response at the implantation site. This was characterised by the development of newly formed blood vessels that grew inside the pores of the biomaterial. They mainly originated from capillaries and postcapillary venules of the host tissue. Consequently, Medpor ${ }^{\circledR}$ implants were finally surrounded by new microvascular networks with a functional capillary density of $180 \mathrm{~cm} / \mathrm{cm}^{2}$ and $140 \mathrm{~cm} /$ $\mathrm{cm}^{2}$ in the border and centre zones at day 14 after implantation (Fig. 2). Interestingly, treatment with prednisolone resulted in a decelerated vascularisation process, as indicated by a significantly decreased number of angiogenesis positive ROIs in the border and centre zones of the implants at day 10 when compared to vehicletreated controls (Fig. 2). Accordingly, Medpor ${ }^{\circledR}$ implants of prednisolone-treated animals presented with a reduced functional capillary density of only $80 \mathrm{~cm} / \mathrm{cm}^{2}$ (border) and $70 \mathrm{~cm} / \mathrm{cm}^{2}$ (centre) at the end of the in vivo experiments (Fig. 2).

\section{Histology}

At day 14 after implantation of Medpor ${ }^{\circledR}$, histological examinations of the dorsal skinfold chamber preparations showed that the implants of both groups were surrounded by a vascularised granulation tissue, filling the pores of the polyethylene biomaterial (Figs. 3A and 3C). Notably, giant cells could be detected at the interface between the implants and the granulation tissue as a typical indicator for a chronic foreign body reaction (Figs. 3B and 3D).

\section{Aortic ring assay}

In line with our intravital microscopic findings, the aortic ring assay demonstrated that prednisolone effectively suppresses angiogenesis. Incubation of Matrigelembedded aortic rings with prednisolone significantly reduced the area, the maximal length and the density of the outer aortic endothelial cell sprouting when compared to control rings (Fig. 4).

\section{Western Blot analysis}

In eEND2 cells, cultured in DMEM-medium supplemented with different doses of prednisolone, expression of important proteins involved in the angiogenic process, i.e. Tie2, VEGF and MMP9, was dose-dependently reduced when compared to controls (Fig. 5). Moreover, prednisolone-treated cells exhibited a dose-dependently decreased expression of the proliferation marker PCNA (Fig. 5). 

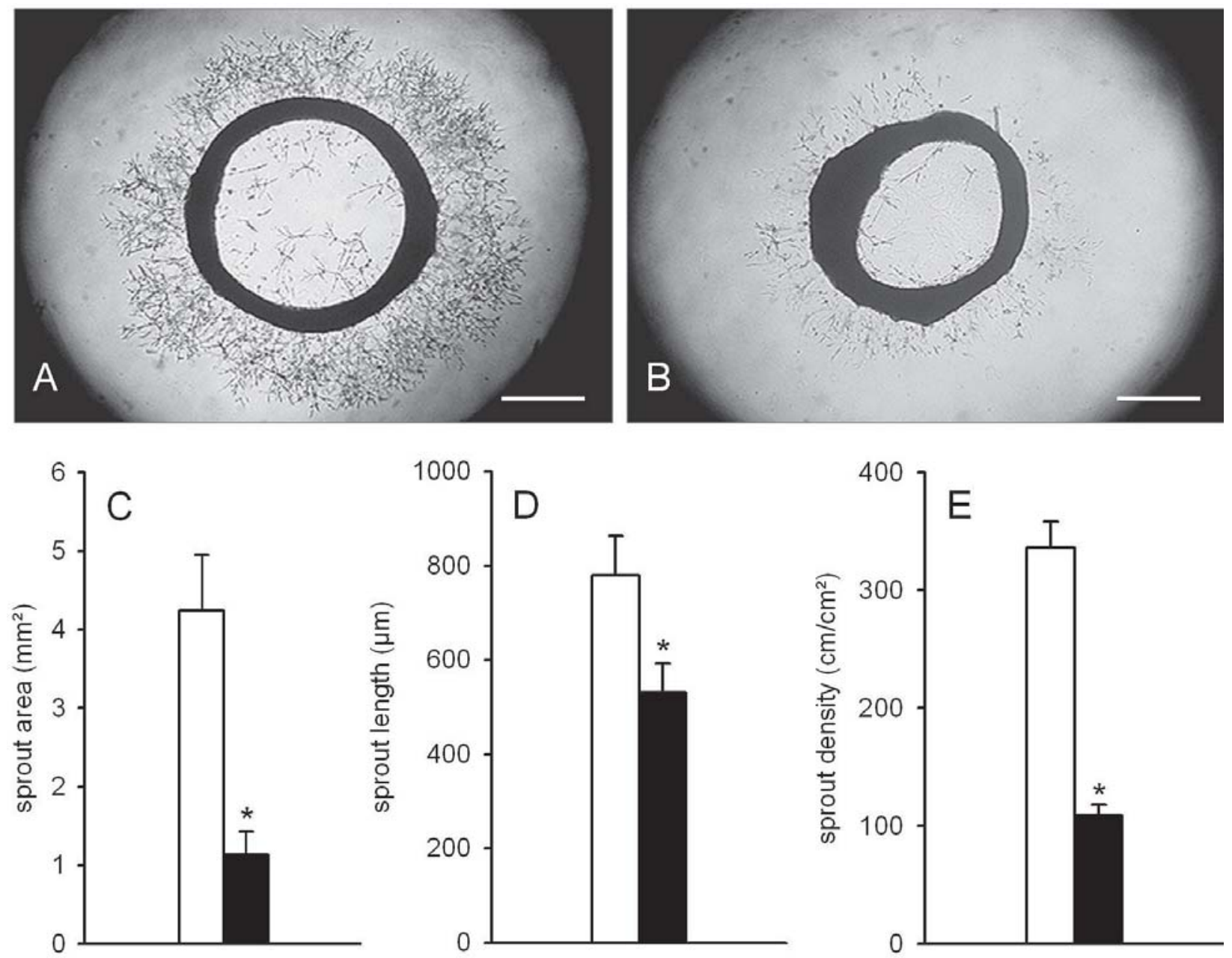

Fig. 4. (A, B) Representative images of aortic rings with vascular sprouting upon 6 days of incubation in DMEM

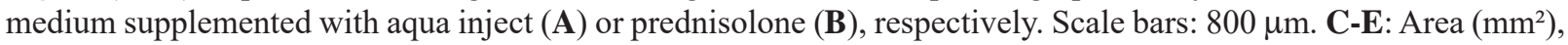
maximal length $(\mu \mathrm{m})$ and density $\left(\mathrm{cm} / \mathrm{cm}^{2}\right)$ of the outer aortic endothelial cell sprouting at day 6 after incubation of aortic rings, which were incubated in DMEM medium supplemented with aqua inject (control, open bars) or prednisolone (closed bars), as assessed by transillumination phase-contrast microscopy and computer-assisted image analysis. Means \pm SEM. ${ }^{*} P<0.05$ vs. control.

\section{Discussion}

In the present intravital microscopic study we analyzed the host tissue response to Medpor ${ }^{\circledR}$, which was implanted into the dorsal skinfold chamber of balb/c mice. In contrast to other studies investigating the incorporation of Medpor ${ }^{\circledR}$ at various implantation sites by means of histological evaluation or serial contrast-enhanced magnetic resonance imaging (MRI) (Uysal et al., 2003; Jordan et al., 2004; Naik et al., 2007), this approach allowed us for the first time to study repetitively the in vivo ingrowth of new blood vessels into Medpor ${ }^{\circledR}$ during the first 14 days after implantation. This observation period may be of particular interest, because early implant vascularization has been proposed to be a crucial determinant for adequate Medpor ${ }^{\mathbb{R}}$ incorporation, minimizing the risk of extrusion, migration and infection (Naik et al., 2007).

We found that perioperative prednisolone treatment significantly inhibited early Medpor ${ }^{\circledR}$ vascularisation when compared to vehicle-treated controls. This finding may be of major importance in clinical practice, because perioperative steroid administration is commonly used in maxillofacial and plastic surgery to reduce postoperative oedema formation and to shorten recovery time (Habal, 1985; Kara and Gökalan, 1999; Kargi et al., 2003). Our novel data indicate that perioperative steroid therapy should be avoided in case of Medpor ${ }^{\circledR}$ implantation to achieve a rapid incorporation of the biomaterial at the implantation site.

The observed anti-angiogenic effect of prednisolone treatment may be attributed to several mechanisms. On the one hand, prednisolone is a potent anti-inflammatory glucocorticoid, which inhibits the activation of various immune competent cells, including T-cells and macrophages, and suppresses the release of several inflammatory cytokines, such as tumour necrosis factor (TNF)- $\alpha$, interferon (IFN)- $\gamma$ and interleukin (IL)-2 (Sloka and Stefanelli, 2005). Moreover, prednisolone has been shown to decrease the expression of important adhesion molecules, mediating leukocyte-endothelial cell interaction, such as E-selectin, intercellular adhesion molecule (ICAM)-1 and vascular cell adhesion molecule (VCAM)-1 (Yoshida et al., 1997; Dufour et al., 1998). Considering the fact that inflammation is one of the most important triggers for angiogenesis (David Dong et al., 2009), prednisolone may have indirectly inhibited the 

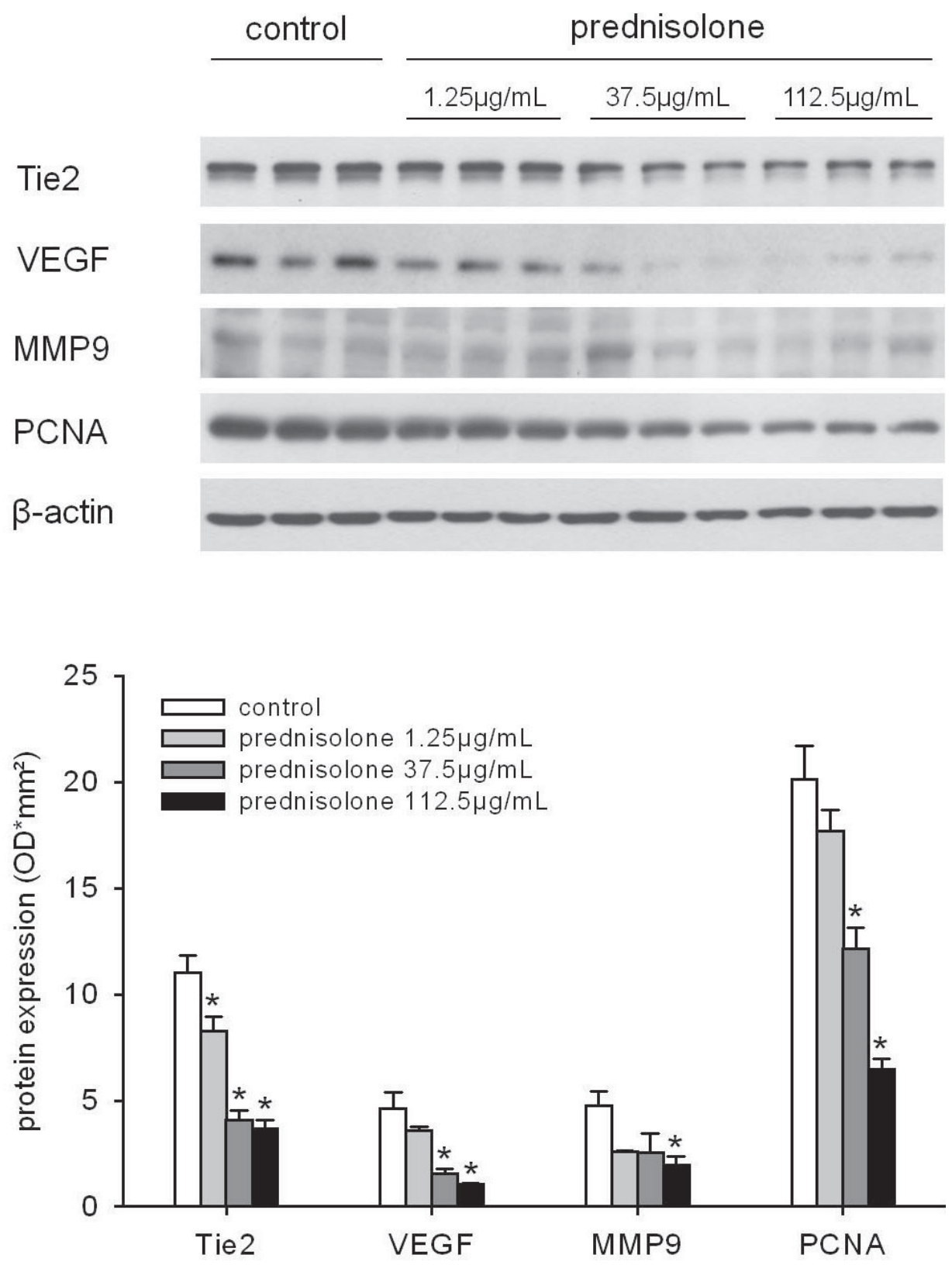

Fig. 5. Western blot analysis of Tie2, VEGF, MMP9 and PCNA protein expression (optical density (OD)*mm²) of eEND2 cells, which were cultured for 24h in DMEM medium supplemented with aqua inject (control, white bars) as well as $1.25 \mu \mathrm{g} / \mathrm{mL}, 37.5 \mu \mathrm{g} / \mathrm{mL}$ and $112.5 \mu \mathrm{g} / \mathrm{mL}$ prednisolone (light grey, dark grey and black bars). Means \pm SEM. $* P<0.05$ vs. control.

vascularisation of Medpor ${ }^{\circledR}$ in the present study by reducing the inflammatory host tissue response to the implants. However, our intravital microscopic results clearly indicate that leukocyte-endothelial cell interaction was not affected by prednisolone treatment. Moreover, histological analysis showed that Medpor ${ }^{\circledR}$ implants induced a comparable foreign body reaction in both experimental groups. Therefore, we suggest that the vascularisation of implanted Medpor ${ }^{\circledR}$ may have rather been inhibited by prednisolone due to direct suppression of angiogenesis. Accordingly, we could demonstrate that prednisolone significantly inhibits endothelial sprouting and tube formation in the aortic ring assay. Furthermore, Western blot analysis revealed that prednisolone dosedependently reduces endothelioma cell proliferation as well as expression of Tie2, VEGF and MMP9. These proteins reflect distinct steps directly involved in the angiogenic process, i.e. activation of intracellular signalling pathways (Tie2), release of pro-angiogenic growth factors (VEGF) and degradation of the extracellular matrix (MMP9) (Carmeliet, 2000). Thus, our results further demonstrate that prednisolone inhibits blood vessel development by targeting multiple angiogenic mechanisms.

Besides the analysis of angiogenesis, we also investigated the in vivo biocompatibility of Medpor ${ }^{\circledR}$. For this purpose, we studied leukocyte-endothelial cell interaction in postcapillary and collecting venules of the chamber tissue located in the border zones of the implants. Of interest, microhaemodynamics of these vessels did not show marked differences between the groups, although salts retention and increase of blood pressure can be induced by prednisolone administration. These results are in line with those of the study of Assimes and Lessard (1999), reporting that short-term use of perioperative 
corticosteroids is normally not associated with hypertension.

The analysis of biocompatibility demonstrated that Medpor $^{\circledR}$ implants did not induce a strong leukocytic inflammatory response. This finding seems not to be surprising as previous studies have also reported an only mild or even absent inflammatory host tissue response to Medpor $^{\circledR}$ (Klawitter et al., 1976; Wellisz, 1993; Niechajev, 1999). Accordingly, Medpor ${ }^{\circledR}$ has been proposed as a standard reference material for biocompatibility testing (Homsy, 1970; Yaremchuk, 2003). Nonetheless, it should be noted that we could detect giant cells at the interface between the implants and the granulation as a typical indicator for a chronic foreign body reaction. These findings are in line with the study of Gosau et al. (2008), further supporting their view that Medpor ${ }^{\circledR}$ cannot be regarded as an immunologically completely inert material.

In summary, we could demonstrate in the present study that Medpor $^{\mathbb{R}}$ does not induce leukocytic inflammation after implantation into the host. Moreover, Medpor ${ }^{\circledR}$ promotes the ingrowth of new blood vessels due to its porous structure, resulting in a good incorporation at the implantation site. Importantly, prednisolone administration significantly inhibits the early vascularisation of Medpor ${ }^{\circledR}$ implants due to the suppression of distinct angiogenic molecules, including Tie2, VEGF and MMP9. Thus, perioperative steroid therapy may not be recommended in case of Medpor ${ }^{\circledR}$ implantation to prevent postoperative complications such as extrusion, migration and infection.

\section{Acknowledgements}

We are grateful for the excellent technical assistance of Janine Becker and Julia Parakenings. This work was supported by the research program of the Medical Faculty of the University of Saarland (HOMFOR 2008).

\section{References}

Assimes TL, Lessard ML (1999) The use of perioperative corticosteroids in craniomaxillofacial surgery. Plast Reconstr Surg 103: 313-321.

Baker M, Wayland H (1974) On-line volume flow rate and velocity profile measurement for blood in microvessels. Microvasc Res 7: 131-143.

Banciu M, Schiffelers RM, Fens MH, Metselaar JM, Storm G (2006) Anti-angiogenic effects of liposomal prednisolone phosphate on B16 melanoma in mice. J Control Release 113: 1-8.

Carmeliet P (2000) Mechanisms of angiogenesis and arteriogenesis. Nat Med 6: 389-395.

David Dong ZM, Aplin AC, Nicosia RF (2009) Regulation of angiogenesis by macrophages, dendritic cells, and circulating myelomonocytic cells. Curr Pharm Des 15: 365-379.

Dufour A, Corsini E, Gelati M, Ciusani E, Zaffaroni M, Giombini S, Massa G, Salmaggi A (1998) Modulation of ICAM-1, VCAM-1 and HLA-DR by cytokines and steroids on HUVECs and human brain endothelial cells. J Neurol Sci 157: 117-121.

Duman H, Deveci M, Uygur F, Sengezer M (1999) Reconstruction of contour and anterior wall defects of frontal bone with a porous polyethylene implant. J Craniomaxillofac Surg 27: 298-301.

Gosau M, Draenert FG, Ihrler S (2008) Facial augmentation with porous polyethylene (Medpor) histological evidence of intense foreign body reaction. $\mathrm{J}$ Biomed Mater Res B Appl Biomater 87: 83-87.

Gürlek A, Fariz A, Aydogan H, Ersöz-Oztürk A, Evans GR (2009) Effects of high dose corticosteroids in open rhinoplasty. J Plast Reconstr Aesthet Surg 62: 650-655.

Habal MB (1985) Prevention of postoperative facial edema with steroids after facial surgery. Aesthetic Plast Surg 9: 69-71.

Hase S, Nakazawa S, Tsukamoto Y, Segawa K (1989) Effects of prednisolone and human epidermal growth factor on angiogenesis in granulation tissue of gastric ulcer induced by acetic acid. Digestion 42: 135-142.

Homsy CA (1970) Biocompatibility in selection of materials for implantation. J Biomed Mater Res 4: 341356.

Jordan DR, Brownstein S, Dorey M, Yuen VH, Gilberg S (2004) Fibrovascularization of porous polyethylene (Medpor) orbital implant in a rabbit model. Ophthal Plast Reconstr Surg 20: 136-143.

Kara CO, Gökalan I (1999) Effects of single-dose steroid usage on edema, ecchymosis, and intraoperative bleeding in rhinoplasty. Plast Reconstr Surg 104: 22132218.

Kargi E, Hosnuter M, Babucçu O, Altunkaya H, Altinyazar C (2003) Effect of steroids on edema, ecchymosis, and intraoperative bleeding in rhinoplasty. Ann Plast Surg 51: 570-574.

Kim MB, Sarelius IH (2004) Regulation of leukocyte recruitment by local wall shear rate and leukocyte delivery. Microcirculation 11: 55-67.

Klawitter JJ, Bagwell JG, Weinstein AM, Sauer BW (1976) An evaluation of bone growth into porous high density polyethylene. J Biomed Mater Res 10: 311-323.

Laschke MW, Häufel JM, Thorlacius H, Menger MD (2005) New experimental approach to study host tissue response to surgical mesh materials in vivo. J Biomed Mater Res A 74: 696-704.

Laschke MW, Witt K, Pohlemann T, Menger MD (2007) Injectable nanocrystalline hydroxyapatite paste for bone substitution: in vivo analysis of biocompatibility and vascularization. J Biomed Mater Res B Appl Biomater 82: 494-505.

Laschke MW, Rücker M, Jensen G, Carvalho C, Mülhaupt R, Gellrich NC, Menger MD (2008) Incorporation of growth factor containing Matrigel promotes vascularization of porous PLGA scaffolds. J Biomed Mater Res A 85: 397-407.

Menger MD, Wolf B, Jäger S, Walter P, Messmer K (1990) The influence of prednisolone on revascularization of pancreatic islet grafts. Transplant Proc 22: 2042-2043.

Morton AD, Nelson C, Ikada Y, Elner VM (2000) Porous polyethylene as a spacer graft in the treatment of 
lower eyelid retraction. Ophthal Plast Reconstr Surg 16: 146-155.

Naik MN, Murthy RK, Honavar SG (2007) Comparison of vascularization of Medpor and MedporPlus orbital implants: a prospective, randomized study. Ophthal Plast Reconstr Surg 23: 463-467.

Niechajev I (1999) Porous polyethylene implants for nasal reconstruction: clinical and histologic studies. Aesthetic Plast Surg 23: 395-402.

Roller J, Laschke MW, Sethi S, Herrmann M, Menger MD (2008) Prolene-Monocryl-composite meshes do not increase microvascular Staphylococcus aureus adherence and do not sensitize for leukocytic inflammation. Langenbecks Arch Surg 393: 349-357.

Rücker M, Laschke MW, Junker D, Carvalho C, Schramm A, Mülhaupt R, Gellrich NC, Menger MD (2006) Angiogenic and inflammatory response to biodegradable scaffolds in dorsal skinfold chambers of mice. Biomaterials 27: 5027-5038.

Rücker M, Laschke MW, Junker D, Carvalho C, Tavassol F, Mülhaupt R, Gellrich NC, Menger MD (2008) Vascularization and biocompatibility of scaffolds consisting of different calcium phosphate compounds. J Biomed Mater Res A 86: 1002-1011.

Sloka JS, Stefanelli M (2005) The mechanism of action of methylprednisolone in the treatment of multiple sclerosis. Mult Scler 11: 425-432.

Uysal A, Ozbek S, Ozcan M (2003) Comparison of the biological activities of high-density porous polyethylene implants and oxidized regenerated cellulosewrapped diced cartilage grafts. Plast Reconstr Surg 112: 540-546.

Wellisz T (1993) Clinical experience with the Medpor porous polyethylene implant. Aesthetic Plast Surg 17: 339344.

Yaremchuk MJ (2003) Facial skeletal reconstruction using porous polyethylene implants. Plast Reconstr Surg 111: $1818-1827$.

Yoshida N, Yoshikawa T, Nakamura Y, Takenaka S, Sakamoto K, Manabe H, Nakagawa S, Kondo M (1997) Methylprednisolone inhibits neutrophil-endothelial cell interactions induced by interleukin- $1 \beta$ under flow conditions. Life Sci 60: 2341-2347.

\section{Discussion with Reviewer}

Reviewer I: The authors suggest that in case of Medpor ${ }^{\circledR}$ implantation, perioperative steroid therapy should be avoided to achieve a rapid incorporation of the biomaterial at the implantation site. However, to my knowledge it is a widespread and common practice to use steroid in CMF notably to reduce oedema, and this suggestion may not be practical in the clinic.

Authors: Based on the present study, we indeed do not longer recommend perioperative steroid administration in case of Medpor $^{\circledR}$ implantation. Although this may prolong the time period of postoperative oedema formation in individual cases, our own clinical experience is that there are no significant differences in terms of the surgical outcomes and aesthetic results of patients who are treated with or without perioperative steroids.

Reviewer I: Did the authors think that what they found in this study is also true for other porous membrane biomaterials use in plastic and reconstruction surgery?

Authors: Our aortic ring assay and Western blot analysis of protein expression in endothelial-like cells clearly demonstrate that prednisolone generally inhibits important steps of the angiogenic process, i.e. tube formation and expression of pro-angiogenic growth factors and matrix metalloproteinases. Therefore, we think that the observed effects of the use of prednisolone on the vascularisation of Medpor ${ }^{\circledR}$ would be comparable for other implanted porous biomaterials. In fact, there is no evidence of a specific chemical or physical reaction between prednisolone and implanted Medpor ${ }^{\circledR}$ in our study. Nonetheless, it should be noted that vascularisation of implanted biomaterials may markedly differ due to other influencing factors, such as material architecture or chemical composition.

Reviewer I: If a steroid therapy cannot be avoided, can the improvement of the biomaterials be a solution? And what would be the solution to improve angiogenesis in the porous membrane (structural, angiogenic factors,...)? Authors: As already stated in our answer to the first question, in clinical practice we do not observe any significant differences in terms of the surgical outcomes and aesthetic results of patients who are treated with or without perioperative steroids. Thus, we feel that there is not really a need for a solution when the use of steroids cannot be avoided. However, if there is a perceived need for faster vascularisation of implanted Medpor ${ }^{\circledR}$, it might indeed be possible to coat Medpor ${ }^{\circledR}$ with angiogenic growth factors, such as vascular endothelial growth factor (VEGF) or basic fibroblast growth factor (bFGF). Alternatively, Medpor ${ }^{\circledR}$ may be incorporated into proangiogenic gels, such as platelet rich plasma (PRP), prior to implantation. This approach bears the advantage that PRP can easily be generated from a patient's blood sample and contains a combination of different angiogenic growth factors that may ideally promote angiogenesis and implant vascularisation. 